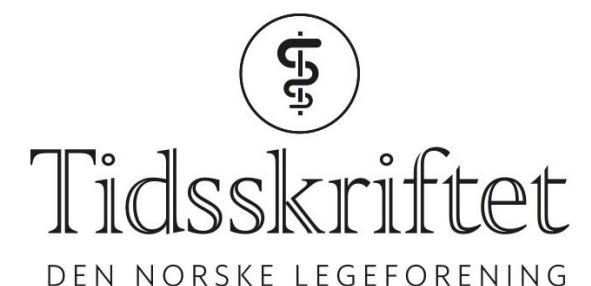

DEN NORSKE LEGEFORENING

\title{
B. Backe svarer
}

KOMMENTAR

\section{BJØRN BACKE}

E-post:bjbac@online.no

Bjørn Backe er professor og dr.med. Ingen oppgitte interessekonflikter.

Mitt hovedbudskap, som Henriksen og medarbeidere unnlater å kommentere, er at svangerskapsdiabetes faktisk ikke er en viktig risikofaktor i svangerskapet. Screening og behandling av svangerskapsdiabetes vil ikke føre til nevneverdig reduksjon i forekomst av nyfødte med høy fødselsvekt. Det vil heller ikke føre til bedre helse, hverken for den gravide eller hennes barn. Kostnadene ved screening og behandling er betydelige og langt større enn nytteverdien (1).

Insulinresistens er fysiologisk i siste trimester. En ting er å definere hva som er «for høyt»; her har man valgt i hvilken grad fosterveksten blir påvirket. En helt annen ting er å iverksette screening og behandling av denne tilstanden som påvirker fosterets vekst. Lærdommen fra de randomiserte, kontrollerte studiene er at den gevinsten man kan håpe på er en beskjeden reduksjon i fødselsvekt.

Socialstyrelsen i Sverige har også innført nye kriterier for svangerskapsdiabetes (som er forskjellige fra de norske), men foreløpig ingen anbefaling om screening. Først vil de avvente en studie for å se effekten av de nye kriteriene (2). Dette står i skarp kontrast til den norske tilnærmingen hvor man gir nye retningslinjer med den oppsiktsvekkende begrunnelsen «å få mer ensartet praksis i landet» (3), hva nå det skal være godt for.

Dagens kunnskapsstatus er - som for 20 år siden (3) - at glukoseintoleranse som utvikles i svangerskapet, ikke er en sykdom som krever diagnostikk og behandling, men en av flere risikofaktorer for stort barn (4). Det er påfallende i hvilken grad dette fagfeltet alltid har vært dominert av sterke interesseorganisasjoner, konsensusgrupper og retningslinjemakere $(3,4)$.

Henriksen og medarbeidere påberoper seg å ha vurdert litteraturen med Grademetodikken (5). Men til tross for at det faglige grunnlaget gjennomgående har lav/svært lav kvalitet har de - uten forbehold - kommet med særdeles omfattende, sykeliggjørende og kostbare retningslinjer. På denne måten forblir begrepet kunnskapsbasert medisin en floskel til festbruk. En mer nøktern tilnærming hadde vært adekvat. Her er det ikke er snakk om å redde nyfødtes liv men - gjennom stor innsats - å oppnå en liten reduksjon i fødselsvekt hos noen få barn. Hvorfor det skulle være viktig er det vanskelig å finne svar på i retningslinjene (5). 
1. Farrar D, Simmonds M, Griffin S et al. The identification and treatment of women with hyperglycaemia in pregnancy: an analysis of individual participant data, systematic reviews, metaanalyses and an economic evaluation. Health Technol Assess 2016; 20:1-348. [PubMed][CrossRef]

2. Gränsvärden för graviditetsdiabetes. Socialstyrelsen, Stockholm, 2015.

http://www.socialstyrelsen.se/riktlinjer/beslutsstodforbehandling/gransvardenforgraviditetsdiabetes (16.5.2018).

3. Backe B. Såkalt svangerskapsdiabetes - en ny folkesykdom?Såkalt svangerskapsdiabetes - en ny folkesykdom? Tidsskr Nor Lægeforen 1997; 117: 852 - 4. [PubMed]

4. Cundy T, Holt RI. Gestational diabetes: paradigm lost?Gestational diabetes: paradigm lost? Diabet Med 2017; 34: 8 - 13. [PubMed][CrossRef]

5. Nasjonal faglig retningslinje for svangerskapsdiabetes. Oslo: Helsedirektoratet, 2017.

https://helsedirektoratet.no/retningslinjer/svangerskapsdiabetes. (16.5.2018).

Publisert: 12. juni 2018. Tidsskr Nor Legeforen. DOI: 10.4045/tidsskr.18.0444

(C) Tidsskrift for Den norske legeforening 2020. Lastet ned fra tidsskriftet.no 